\title{
The Possible Role of DL-Methionine in the Detoxification of Gliricidia Leaf Anti-nutrients in Rabbit Nutrition
}

\author{
J H Edoh, A A Annongu, F M Houndonougbo, A O Ajayi, C A A M Chrysostome
}

\begin{abstract}
A feeding trial was performed to investigate the potential of methionine as detoxifying agent of secondary metabolites present in Gliricidia sepium leaf. The leaves were dried, milled, and included in rabbit diets at 0 (D0, control), 10 (D10) and $15 \%(\mathrm{D} 15)$ raw and at $10\left(\mathrm{D}_{\mathrm{SM}} 10\right)$ and $15 \%\left(\mathrm{D}_{\mathrm{SM}} 15\right)$ with $0.3 \%$ DL-methionine supplementation. 60-weaned rabbits (of 7-weeks old) averaging $1066 \pm 16.3 \mathrm{~g} / \mathrm{rabbit}$ were used and fed the 5-diets (ad libitum) over a feeding trial lasting 6-weeks. At the end of the feeding trial, 6 rabbits were sampled per treatment for digestibility tests and 6 other for carcass characteristics. The experiment was designed as a one way classification. Proximate analysis and quantification of GLM phytochemicals revealed that $G$. sepium leaves are potentially rich in nutrients but contain substantial amount of antinutrients namely tannins, phytic and oxalic acids, alkaloids and saponins. Dietary performance traits gave no significant differences $(p>0.05)$ in feed consumption, body weight gain and feed conversion ratio on the test diets relative to the control diet. The digestibility of dry matter, organic matter and crude protein decreased with increasing level of GLM. Supplementation of methionine to the feeds containing GLM had slightly improved the digestibility rates though the improvement was not significant $(p>0.05)$. Feeding cost and economic feed efficiency were better in rabbits fed the diet D10 but not significant $(P>0.05)$. Carcass characteristics were not significantly $(p>0.05)$ affected by diets. Conclusively GLM at 10 or $15 \%$ inclusion in diets with or without methionine supplementation elicited no untoward effects on dietary performance traits and carcass characteristics of the rabbits. Methionine supplementation for detoxification should be carried out along with other chemical detoxicants to enable the inclusion of the leaf meal at higher levels.
\end{abstract}

Index Terms- Bio-economic parameters, metabolic detoxification, Oryctolagus cuniculus, secondary metabolites, sulfur amino acid.

\section{INTRODUCTION}

Short generation interval animals like poultry, rabbit, rodent, insect, fish etc., occupy prominent positions in

EDOH Johannes Hugues, Ecole des Sciences et Techniques de Production Animale, Faculté des Sciences Agronomiques, Université d'Abomey Calavi, 01 BP 526 Cotonou, République du Benin

ANNONGU Amos Azor, Department of Animal Production, Faculty of Agriculture P.M.B. 1515 University of Ilorin, Nigeria

HOUNDONOUGBO Mankpondji Frederic, Ecole des Sciences et Techniques de Production Animale, Faculté des Sciences Agronomiques, Université d'Abomey Calavi, 01 BP 526 Cotonou, République du Benin, AJAYI Amos Olakunle, Department of Animal Production, Faculty of Agriculture P.M.B. 1515 University of Ilorin, Nigeria

CHRYSOSTOME C A A M, Ecole des Sciences et Techniques de Production Animale, Faculté des Sciences Agronomiques, Université d'Abomey Calavi, 01 BP 526 Cotonou, République du Benin providing animal protein, contributing significantly to the rural households in developing countries and in meeting the rapidly growing demand for animal products [1]. Rabbit meat is well appreciated by Beninese and the animal production is drawing more attention than ever before. In 1992, more than $64 \%$ of the population has once consumed rabbit meat and $95 \%$ of them delighted it [2]. However rabbit industry is also facing the problem of increasing cost of feeding which account for about $60-65 \%$ of its production expenses [3]. This situation is due to the competition that exists among humans, animals and industries for the available grains. Moreover, increased industrial use of grains has led to a sharp rise in the prices of feeds/foodstuffs. To tackle this problem, livestock industry could strive on the use of nonconventional feedstuffs in animal diets [4].

One possible source of available and cheap feedstuffs is the leaf meals of some tropical legume browse plants of appreciable primary metabolites (protein, carbohydrate, fat, etc.). However, the constraints militating against the enhanced utilisation of leaf meals reside chiefly in the presence of secondary metabolite compounds (tannins, saponins, alkaloids, phytates, etc.) that elicit toxic and/or physiological effects on the animal body when consumed in amounts above the normal threshold [5], [6]. Therefore, if their feeding value is improved, many unconventional feedstuffs could alternatively be fed at cheaper cost to monogastric animals like rabbits.

In view of the forth going, Gliricidia sepium leaf meal appears to be an ideal plant material to be evaluated. That why this study aims at evaluating the detoxification potential of synthetic methionine on the dietary leaf meal in rabbit nutrition. Hence methionine has been reported to overcome in some cases, the dietary effects of some anti-nutrients by metabolic detoxification [7], [8], [9].

\section{MATERIALS AND METHODS}

\section{A. Experimental site}

The field work for this study was performed on the Research farm of the Faculty of Agriculture (FSA/UAC, Republic of Benin). 


\section{B.Preparation of the test feedstuff}

Fresh Gliricidia leaves have been harvested in the vicinity of the University of Abomey-Calvi, and processed as describe by $[10]$.

\section{Experimental diets, animals and feeding trial}

60 -local breeds of rabbit kits ( $49 \pm 2$ days old) with an average of $1066 \pm 16.3 \mathrm{~g} / \mathrm{rabbit}$ were used for the assay. The rabbits were randomly assigned to 5-dietary treatments with 12-rabbits per diet and each diet made of 4-replicates of 3-rabbits each. Each replicate of the experimental rabbits being accommodated in a hutch seized: $80 \times 50 \times 30 \mathrm{~cm} 3$ (length $\times$ width $\times$ height).

The experimental diets were similar in nutrient content. They contain 0 (D0, control), 10 (D10) and 15\% (D15) of raw GLM, and $10 \quad\left(\mathrm{D}_{\mathrm{SM}} 10\right)$ and $15 \%\left(\mathrm{D}_{\mathrm{SM}} 15\right)$ of GLM supplemented with $0.3 \%$ DL-methionine. The feeding trial lasted 6-weeks and the composition and nutrient content of the experimental diets is presented on Table 1.

Table 1: Composition and nutrient content of the experimental diets

\begin{tabular}{|c|c|c|c|c|c|}
\hline Ingredients (\%) & $\mathrm{D}^{1}$ & D10 & $\mathrm{D}_{\mathrm{SM}} 10^{2}$ & D15 & $\mathrm{D}_{\mathrm{SM}} 15$ \\
\hline GLM & 0.00 & 10.00 & 10.00+Met & 15.00 & $15.00+\mathrm{Met}$ \\
\hline Maize & 20.00 & 18.00 & 18.00 & 16.00 & 16.00 \\
\hline Palm kernel meal & 29.00 & 25.00 & 25.00 & 25.00 & 25.00 \\
\hline Cottonseed meal & 7.00 & 7.00 & 7.00 & 7.00 & 7.00 \\
\hline Soybean meal & 9.00 & 7.00 & 7.00 & 7.00 & 7.00 \\
\hline Wheat offal & 30.70 & 28.70 & 28.40 & 25.70 & 25.40 \\
\hline Palm oil & 1.00 & 1.00 & 1.00 & 1.00 & 1.00 \\
\hline Oyster shell & 1.70 & 1.70 & 1.70 & 1.70 & 1.70 \\
\hline $\mathrm{NaCl}$ (Salt) & 0.30 & 0.30 & 0.30 & 0.30 & 0.30 \\
\hline Lysine & 0.10 & 0.10 & 0.10 & 0.10 & 0.10 \\
\hline Methionine & - & - & 0.30 & - & 0.30 \\
\hline Premix $^{3}$ & 0.20 & 0.20 & 0.20 & 0.20 & 0.20 \\
\hline Di-calcium Phosphate & 1.00 & 1.00 & 1.00 & 1.00 & 1.00 \\
\hline Total & 100 & 100 & 100 & 100 & 100 \\
\hline Feed price $(\mathrm{F} \mathrm{CFA} / \mathrm{kg})^{4}$ & 232.31 & 215.51 & 228.53 & 209.21 & 222.23 \\
\hline \multicolumn{6}{|c|}{ Nutrient content of the diets } \\
\hline Digestible Energy (Kcal/Kg) & 2688.07 & 2745.67 & 2756.32 & 2777.52 & 2795.12 \\
\hline Crude Protein $(\%)$ & 17.47 & 17.16 & 17.29 & 17.18 & 17.52 \\
\hline Crude Fibre (\%) & 9.31 & 9.73 & 9.70 & 10.06 & 10.01 \\
\hline
\end{tabular}

${ }^{1}$ D0, D10, and D15 are diets containing 0, 10, and 15\% of raw Gliricidia Leaf Meal (GLM), respectively.

${ }^{2} \mathrm{D}_{\mathrm{SM}} 10$, and $\mathrm{D}_{\mathrm{SM}} 15$ are diets containing respectively 10 , and $15 \%$ of Gliricidia Leaf Meal, supplemented with Methionine.

${ }^{3} 800000$ UI, E $2000 \mathrm{mg}$, K $800 \mathrm{mg}$, B1 $600 \mathrm{mg}$, B2 $2000 \mathrm{mg}$, niacin $3600 \mathrm{mg}$, B6 $1200 \mathrm{mg}$, B12 4mg, choline chloride 80000 mg; Minerals: Cu 8000 mg, Mn 64000 mg, Zn 40000 mg, Fe 32000 mg, and Se 160 mg;

${ }^{4}$ Republic of Benin Currency: $1 €=655.9$ F CFA.

\section{D.Digestibility study}

At the end of the feeding trial, six rabbits were randomly selected per dietary treatments. The rabbits (similar in weight $\mathrm{p}>0.05$ ) were randomly penned in individual digestibility cage and accommodated for seven days. During the accommodation period, the experimental animals were fed $a d$ libitum their respective diets. To empty their digestive tract, the rabbits were fasted for 24 hours prior the startup of the digestibility assay. Throughout the fasting period, water and vitamin was delivered as anti-stress. During seven days, feed intake was recorded on each rabbit. Besides, faeces excreted were collected daily and oven dried to determine moisture content. Then proximate analysis of the experimental diets and representative faecal samples was performed. Finally, apparent digestibility coefficient of dry matter (dDM), organic matter $(\mathrm{dOM})$ and crude protein $(\mathrm{dCP})$ was calculated as following:

$$
\begin{aligned}
& d D M(\%)=\frac{\text { DM intake }- \text { DM exceted in faeces }}{\text { DM intake }} \times 100 \\
& d O M(\%)=\frac{\text { OM intake }- \text { OM exceted in faeces }}{\text { OM intake }} \times 100 \\
& d C P(\%)=\frac{\text { CP intake }- \text { CP exceted in faeces }}{\text { CP intake }} \times 100
\end{aligned}
$$

\section{E. Carcass characteristics}

For the examination of carcass quality, six rabbits were selected per treatment. The rabbits selected were closest to the treatment mean weight of the replicate. The selected rabbits were deprived from feed for 24 hours. During the fasting period, they were served water and vitamins as anti-stress. Thereafter the animals were stunned by neck hitting and bled by severing the jugular vein. The skin was removed by flaying and the rabbits eviscerated. Then the full digestive tract, hot carcass, and abdominal fat were weighted and expressed as percentage of live body weight according to Blasco and Ouhayoun [11] standards.

\section{F. Chemical analyses}

Proximate analysis of GLM was carried out using the methods described by AOAC [12]. Total Nitrogen (N) was assessed by the micro-Kjeldahl method [13] while the crude protein was computed by multiplying $\% \mathrm{~N}$ with a factor of 6.25. Soluble carbohydrate (NFE) was obtained by subtracting the sum of the percentage of crude protein, ether extracts (EE), crude fibre (CF) mineral matter from dry matter (DM). Anti-nutrients determination of tannins, phytic acid, total oxalate, saponins and alkaloids was conducted by 
the methods of [14], [15], [16], [17] modified by [18], [19] respectively.

\section{G.Statistical analysis}

Data on chemical composition of raw GLM samples were interpreted by descriptive statistics while all the rest of the data were subjected to analysis of variance (ANOVA) using general linear model (GLM) in $\mathrm{R}$ version 3.0.2. The performances of rabbits were compared using each cage of three rabbits as replication. Replication effect and interaction between diets and replications were not significant $(\mathrm{P}>0.05)$. Thus, analyses were performed according to the model as follows:

$$
Y \vec{i}=\mu+F i+\varepsilon i
$$

Where:

$Y i$ is the observation for dependent variables;

$\mu$ the general mean;

$F i$ the fixed effect of the feed and

$\varepsilon i$ the residual error.

\section{RESULTS}

\section{A. Chemical composition of Gliricidia Leaf Meal (GLM)}

Table 2 gives data on proximate composition of Gliricidia Leaf Meal (GLM). GLM is observed to contain valuable nutrients namely soluble carbohydrate, crude protein, fat, fibre, mineral matter and dry matter in the range of 44.49 ; $16.34 ; 4.73 ; 15.31 ; 10.46$ and $91.33 \%$ respectively.

Table 2: Proximate Analysis of GLM

\begin{tabular}{lc}
\hline Nutrient & \% Content \\
\hline Dry matter (DM) & 91.33 \\
Crude protein (CP) & 16.34 \\
Crude fibre (CF) & 15.31 \\
Ether extract (EE) & 04.73 \\
Mineral matter (Total ash) & 10.46 \\
Soluble carbohydrate (NFE) & 44.49 \\
\hline NB: Proximate values are determined from an average of two (2) \\
determinations for each nutrient.
\end{tabular}

The phytochemical quantification of some of the toxins (anti-nutrients) in the leaf of G. sepium is presented on table 3. The leaf is found to contain high levels of tannins $(23.78 \%)$, alkaloids $(5.77 \%)$ and saponins $(2.04 \%)$ and moderate level of anti-metals (Phytic acid, $16 \mathrm{mg} / 100 \mathrm{~g}$ and oxalic acid, $25.42 \mathrm{mg} / 100 \mathrm{~g}$ ).
Table 3: Quantification of GLM anti-nutrients

\begin{tabular}{lc}
\hline Phytochemical & Concentration \\
\hline Tannins $(\mathrm{g} / 100 \mathrm{~g})$ & $23.78 \pm 0.01$ \\
Phytic acid $(\mathrm{mg} / 100 \mathrm{~g})$ & $16.00 \pm 0.005$ \\
Oxalic acid $(\mathrm{mg} / 100 \mathrm{~g})$ & $25.42 \pm 0.0015$ \\
Saponins $(\mathrm{g} / 100 \mathrm{~g})$ & $02.04 \pm 0.15$ \\
Akaloids $(\mathrm{g} / 100 \mathrm{~g})$ & $05.77 \pm 0.25$ \\
\hline NB: Values of the phytochemical concentration are taken from average of \\
three (3) determinations for each anti-nutrient.
\end{tabular}

\section{B. Feed intake of growing rabbits}

During the experiment, the daily feed intake of rabbits fed with the five diets (Figure 1) was not significantly different $(\mathrm{P}>0.05)$. However the lowest feed intake registered was in the control diet $(77.47 \pm 7.41 \mathrm{~g} / \mathrm{d})$ while the experimental diets consumption was $87.34 \pm 6.46 \mathrm{~g} / \mathrm{d} ; 86.31 \pm 1.51 \mathrm{~g} / \mathrm{d}$; $84.42 \pm 5.69 \mathrm{~g} / \mathrm{d}$; and $81.31 \pm 8.47 \mathrm{~g} / \mathrm{d}$ respectively for rabbits fed the diets D10, $\mathrm{D}_{\mathrm{SM}} 10, \mathrm{D} 15, \mathrm{D}_{\mathrm{SM}} 15$. Then the average feed consumption, despite disparities observed during the experiment, was higher with diets containing $10 \%$ of GLM supplemented or not.

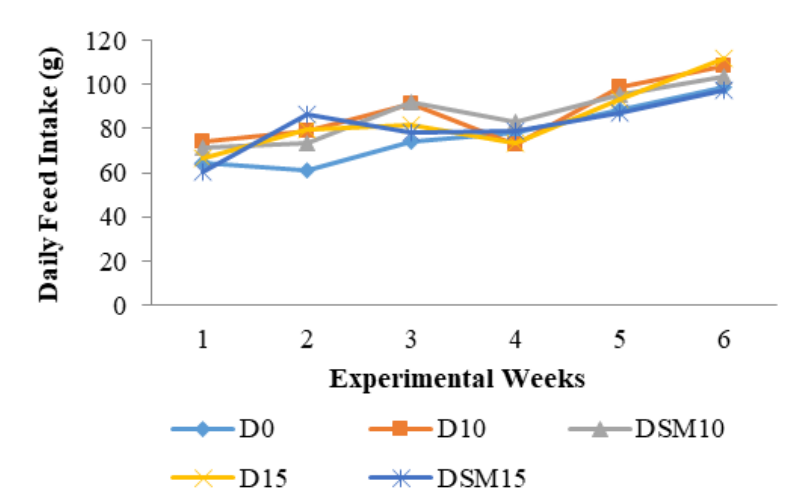

Figure 1: Average daily feed intake of growing rabbits fed diets containing GLM supplemented with or without methionine.

\section{C.Digestibility of diets}

Incorporation of GLM in the rabbit diets had significantly reduced $(\mathrm{P}<0.05)$ the digestibility of dry matter $(\mathrm{dDM})$, organic matter (dOM) and crude protein (dCP) (Table 4). Besides, supplementation of methionine to the feed containing GLM had slightly improved the digestibility rate of those parameters. However, that improvement of the apparent digestibility was not significant $(\mathrm{p}>0.05)$.

Table 4: Apparent Digestibility (\%) of dry matter, organic matter and crude protein for rabbits fed diets containing GLM treated with or without Methionine

\begin{tabular}{lccccccc}
\hline & $\mathrm{D}^{1}$ & $\mathrm{D} 10$ & $\mathrm{D}_{\mathrm{SM}} 10^{2}$ & $\mathrm{D} 15$ & $\mathrm{D}_{\mathrm{SM}} 15$ & $\mathrm{SEM}^{3}$ & ${ }^{4} \mathrm{P}$ \\
\hline $\mathrm{dDM}(\%)$ & $77.71 \pm 3.41 \mathrm{a}$ & $70.33 \pm 1.14 \mathrm{~b}$ & $72.91 \pm 1.73 \mathrm{~b}$ & $68.54 \pm 3.34 \mathrm{~b}$ & $70.22 \pm 2.15 \mathrm{~b}$ & 1.601 & 0.0011 \\
$\mathrm{dOM}(\%)$ & $80.32 \pm 3.02 \mathrm{a}$ & $74.15 \pm 0.99 \mathrm{~b}$ & $75.10 \pm 1.60 \mathrm{~b}$ & $70.57 \pm 3.12 \mathrm{~b}$ & $71.85 \pm 2.04 \mathrm{~b}$ & 1.685 & 0.0003 \\
$\mathrm{dCP}(\%)$ & $80.03 \pm 3.06 \mathrm{a}$ & $74.96 \pm 0.96 \mathrm{~b}$ & $76.85 \pm 1.48 \mathrm{ab}$ & $74.64 \pm 2.69 \mathrm{~b}$ & $74.84 \pm 1.82 \mathrm{~b}$ & 1.022 & 0.0133 \\
\hline
\end{tabular}

dDM: digestibility of dry matter; dOM: digestibility of organic matter; dCP: digestibility of crude protein

${ }^{I} \mathrm{D} 0, \mathrm{D} 10$, and $\mathrm{D} 15$ are diets containing 0,10 , and $15 \%$ of non-supplemented Gliricidia Leaf Meal (GLM), respectively.

${ }^{2} D_{S M} 10$, and $D_{S M} 15$ are diets containing respectively 10, and $15 \%$ of Gliricidia Leaf Meal, supplemented with Methionine.

${ }^{3}$ SEM: Standard error of mean, $P$ : probability

\section{D.Growth Performance of Rabbits}

The growth of rabbits was regular during the experiment (Figure 2). The daily body weight gains (Table 5) were similar between diets $(\mathrm{P}>0.05)$. Consequently, the final body weights between rabbits fed the diets D0 (1999.17 g), D10 (2106.67 g), $\mathrm{D}_{\mathrm{SM}} 10$ (2052.5 g), D15 (1978.75 g) and $\mathrm{D}_{\mathrm{SM}} 15$ $(1980.56 \mathrm{~g})$ were statistically similar $(\mathrm{P}>0.05)$. 


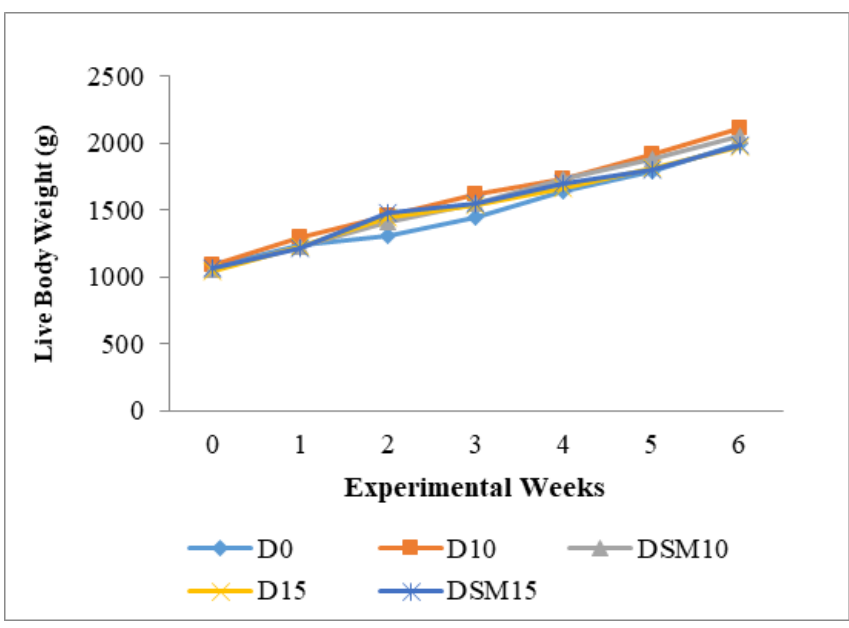

Figure 2: Growth curve of rabbits fed diets containing GLM supplemented with or without methionine.

\section{E. Efficiency of Feeds}

The feed conversion ratio, feeding cost and economic feed efficiency (Table 5) was not statistically affected by dietary treatment. However, the lowest feed conversion ratio was recorded on rabbits fed the $\mathrm{D}_{\mathrm{SM}} 10$ diet while the lowest Feeding cost was registered on rabbits fed the diet D10. The economic feed efficiency that reports the revenue from the live body weight gain comparatively to the feeding cost, was highest in the diet D10, followed by the diet D15.

\section{F. Carcass characteristics}

The carcass yields of rabbits were similar $(\mathrm{P}>0.05)$ between dietary treatments (Table 6). Additionally, the relative weight of digestive tract and abdominal fat expressed as percentage of live weight were not significantly influenced by dietary treatment $(\mathrm{p}>0.05)$.

Table 5: Daily weight gain (g), feed conversion ratio (g feed/g BWG1), feeding cost (FCFA2feed/kg BWG), and economic feed efficiency (FCFA BWG/FCFA feed) of rabbits fed diets containing GLM supplemented with or without Methionine

\begin{tabular}{lccccccc}
\hline & $\mathrm{D}^{1}$ & $\mathrm{D} 10$ & $\mathrm{D}_{\mathrm{SM}} 10^{2}$ & $\mathrm{D} 15$ & $\mathrm{D}_{\mathrm{SM}} 15$ & $\mathrm{SEM}^{3}$ & ${ }^{4} \mathrm{P}$ \\
\hline DWG $(\mathrm{g})$ & $22.08 \pm 1.94$ & $24.25 \pm 3.60$ & $23.71 \pm 3.72$ & $22.23 \pm 2.74$ & $20.40 \pm 2.22$ & 0.678 & 0.4071 \\
FCR & $4.78 \pm 1.06$ & $4.03 \pm 0.97$ & $3.97 \pm 1.01$ & $4.86 \pm 1.15$ & $6.05 \pm 1.58$ & 0.376 & 0.1376 \\
FC & $1111 \pm 247$ & $866 \pm 209$ & $906 \pm 232$ & $1017 \pm 241$ & $1346 \pm 352$ & 85.60 & 0.1243 \\
EFE & $2.09 \pm 0.27$ & $2.24 \pm 0.5$ & $2.10 \pm 0.34$ & $2.20 \pm 0.21$ & $1.88 \pm 0.33$ & 0.062 & 0.6321 \\
\hline
\end{tabular}

DWG: Daily weight gain, FCR: Feed conversion ratio, FC: Feeding cost, economic feed efficiency, BWG: Live body weight gain, Currency: $1 €=655.9$ FCFA.

Table 6: Carcass yield, full digestive tract and abdominal fat weight of growing rabbits expressed as percentage of live weight

\begin{tabular}{|c|c|c|c|c|c|c|c|}
\hline & $\mathrm{D}^{1}$ & D10 & $\mathrm{D}_{\mathrm{SM}} 10^{2}$ & D15 & $\mathrm{D}_{\mathrm{SM}} 15$ & $\mathrm{SEM}^{3}$ & ${ }^{4} \mathrm{P}$ \\
\hline $\mathrm{Ca}$ & $66.61 \pm 1.65$ & $66.02 \pm 2.20$ & $66.22 \pm 2.33$ & $65.24 \pm 1.83$ & $64.3 \pm 2.58$ & .411 & 0.102 \\
\hline ive tract $(c$ & $15.5 \pm 2.07$ & $15.25 \pm 2.56$ & $15.73 \pm 1.91$ & $15.77 \pm 3.06$ & $18.59 \pm 3.40$ & 0.612 & 0.411 \\
\hline Abdominal fat (\%) & $1.26 \pm 0.33$ & $1.36 \pm 0.30$ & $1.10 \pm 0.18$ & $0.71 \pm 0.52$ & $0.88 \pm 0.29$ & 0.119 & 0.093 \\
\hline
\end{tabular}

${ }^{1}$ D0, D10, and D15 are diets containing 0, 10, and 15\% of unsupplemented Gliricidia Leaf Meal (GLM), respectively.

${ }^{2} \mathrm{D}_{\mathrm{SM}} 10$, and $\mathrm{D}_{\mathrm{SM}} 15$ are diets containing respectively 10 , and $15 \%$ of Gliricidia Leaf Meal, supplemented with Methionine.

${ }^{3} \mathrm{SEM}$ : Standard error of mean, ${ }^{4} \mathrm{P}$ : probability

\section{DISCUSSION}

\section{A. Chemical composition of Gliricidia Leaf Meal (GLM)}

Data on Proximate composition of GLM shows that the leaf contains valuable nutrients. These values, except the protein content fell within the range of nutrients early reported for G. sepium by [20]. Actually, its protein content is lower than values observed by [20], [21], [22], [23], [24]; meanwhile it is higher than that obtains by [25] in Nigeria. So, if the constraints militating against the enhanced utilisation of the leaf of G. sepium are handled, that is its content of anti-nutritional factors, it may provide valuable unconventional alternative feedstuff for domestic animals especially monogastrics that exert high demand on nutrients particularly energy, protein and micronutrients. These could be of nutritional advantage to the fed animals when the nutritive value of the leaf is improved.

Quantitative determination of some of the toxic or anti-nutritional factors in GLM in this experiment revealed high levels of tannins, alkaloids and saponins while containing moderate level of phytic and oxalic acids. These contents of anti-nutrients in GLM agree with other reports which indicate presence of tannins, phytin, oxalate, alkaloids in the leaf [22], [23], [26]. Besides, GLM have been reported by [24] to contain cyanides. Cyanides derive from hydrolysis of cyanogens which suppress natural respiration and provoke cardiac arrest [27]. However no exact limit of toxicity of cyanide for monogastric animals has been reported yet and more studies are required to find out the cyanide level of tolerance for rabbit. G. sepium has also been implicated in the content of a non-protein amino acid and the possiblility of coumarin, a low molecular weight phenolic compound [28], [29].

Although the leaf of G. sepium is shown to contain valuable nutrients, feeding the leaves direct to domestic animals in diets or as sole feedstuff may not be beneficial to the fed animals due to the presence of anti-nutrients.

\section{B. Digestibility study}

The incorporation of GLM in the rabbit diets reduced the digestibility of dry matter (dDM), organic matter (dOM) and crude protein $(\mathrm{dCP})$. The digestibility of dry matter (68.54 to $77.71 \%$ ) observed is higher than values (62 to $67 \%$ ) obtained by [30], [31] in rabbits, but lower than dry matter intake (77.62 to $85.99 \%$ ) recorded by [32] [33].

The decrease of organic matter and crude protein digestibility with the inclusion of GLM in diet could be due to the presence of anti-nutritional factors which interfere with the utilisation of dietary nutrients in a various ways, including the reduction of protein digestibility, binding to various nutrients or damaging the gut wall [34] and thereby depressing digestive efficiency [35]. Previous researchers [36], [37], [38] reported that the presence of secondary metabolites ranging from tannins, oxalates, phytates and saponins may greatly reduce digestibility. 
Tannins form complexes with carbohydrates and proteins in feeds, and with digestive enzymes. Consequently nutrient digestibility is lowered. Other effects of tannins include reduced feed consumption and absorption of some minerals, increased damage to the gut wall, [39], [40], [41].

Oxalates have been reported to: $(i)$ form complexes with mineral ( $\mathrm{Na}, \mathrm{K}, \mathrm{Ca}, \mathrm{Fe}$ and $\mathrm{Mg}$ ) thereby rendering them inaccessible to Animals; (ii) cause irritation of the gut and resulting in low feed consumption, (iii) inhibit energy and protein utilisation in broilers [40].

Phytic acid is reported to reduce the availability of a variety of minerals (calcium, cobalt, copper, magnesium, manganese, selenium, iron and zinc) through complexes binding. Phytic acid can also form complexes with basic residues of proteins and may interfere with the activity of endogenous enzymes and digestibility of nutrients other than minerals [34].

Beside the depressive effect of GLM on dDM, dOM and $\mathrm{dCP}$, supplementation of methionine to the GLM containing feed had slightly improved the digestibility rate of those parameters. However, that improvement of the apparent digestibility was not significant. this finding is congruent with the works of [42] who found that the addition of $0.3 \%$ L-methionine and $0.3 \%$ choline chloride to black locust meal in the diet of New Zealand White rabbits increased ADF digestibility and gave a slight, although not significant, increased of protein digestibility. Also, [43] found that supplementation of methionine to Shea kernel cake in broilers' diets abolished or prevented the ill-effect caused by saponin in the cake. Dietary supplementation with methionine is shown to prevent the deleterious effects by inactivation of the saponins thereby stepping up the nutrient content of the saponin containing diet [44]. In addition to its effect on saponin, supplementation with L-methionine or its hydroxyl analog had been shown to overcome the detrimental effect of condensed tannins of sorghum in chicks [9], but not in rats [45] and Swine [46]. Although methionine supplementation was effective against tannic acid, this beneficial effect of methionine detoxification by donating methyl group was not evidence by a lack of effect of supplemental choline, another methyl donor [34].

\section{Growth Performance of Rabbits and Efficiency of Feeds}

Table on dietary performance of rabbits fed $G$. sepium leaf meal at 10 and $15 \%$ level treated with or without methionine gave no significant differences in feed consumption, body weight gain and feed conversion ratio suggesting that GLM in diets at 10 or $15 \%$ inclusion treated with or without methionine has no adverse effect on performance traits. The growth rates of the experimental rabbits $(20.40$ to $24.25 \mathrm{~g} / \mathrm{d}$ ) were close to values ( 15.72 to $23.1 \mathrm{~g} / \mathrm{j}$ ) reported in Benin in similar rabbit breed [33], [47], [48]. Compared to the reference diet D0 $(22.08 \mathrm{~g} / \mathrm{d})$, the diets D10 $(24.25 \mathrm{~g} / \mathrm{d})$ and $\mathrm{D}_{\mathrm{SM}} 10(23.71 \mathrm{~g} / \mathrm{d})$ did ameliorate the growth performance of rabbits without any deleterious effect on their survivalability. Likewise the final body weights were best in diets D10 $(2106.67 \mathrm{~g})$ and $\mathrm{D}_{\mathrm{SM}} 10(2052.5 \mathrm{~g})$ implying that at $10 \%$ of inclusion in diet, rabbits perfectly cope the anti-nutrient factors in GLM.

The lowest feed conversion ratio recorded in rabbits fed the diet $\mathrm{D}_{\mathrm{SM}} 10$ indicate supplemental effect of methionine on GLM at $10 \%$ inclusion. But the lowest feeding cost register in rabbits fed the diet D10 reveal that beside the beneficial effect of methionine supplementation on feed utilisation in rabbits, no methionine supplementation at all is economically advantageous. Moreover values of economic feed efficiency confirm that tendency. Actually, the highest economic feed efficiency reported in diet D10 (2.24 FCFA weight gain/FCFA feed), followed by the diet D15 (2.20 FCFA weight gain/FCFA feed) demonstrate that GLM included raw in growing rabbit diet at 10 and $15 \%$ is more profitable than supplemented with methionine at $0.3 \%$. This is due to the high cost of that amino-acid compared to other feed ingredients.

\section{D.Carcass characteristics}

The carcass yields (64.3 to $66.22 \%$ ) in rabbits fed the experimental diets are lower than those fed the control diet $(66.61 \%)$ though differences among dietary treatments are not significant $(p>0.05)$. Also the carcass yield tends to decrease with increasing value of GLM in diets. This could be due to the increasing value of fibre intake by the experimental rabbits. However those carcass yield values observed are higher than values obtained by [48], [49] while similarly close to rates $(64.8$ to $66.6 \%)$ reported by [50]. GLM-Based diets did not significantly affect the relative weight of the rabbits' digestive tracts. Also, it does not statistically influence the proportion of abdominal fat though numerically lower in diets D15 and $\mathrm{D}_{\mathrm{SM}} 15$ probably due to higher level of GLM incorporation. These findings show suitable impact GLM based diets on the quality of rabbit carcass.

\section{V.CONCLUSION}

This experiment indicated no adverse effect of GLM on Nutrients utilisation rate, performance and carcass traits of growing Rabbits. Researches are in progress to investigate the inclusions of methionine and choline chloride together to enable inclusion of GLM at levels higher than the 10 and $15 \%$ used in this study.

\section{ACKNOWLEDGMENT}

The authors are grateful to "Bouge GNO" for facilitating the realisation of this experiment by offering the animal material.

\section{REFERENCES}

[1] Wilson R T (2011). Small animals for small farms (Second edition). Rural Infrastructure and Agro-industries Division, Food and Agriculture Organization of the United Nation (FAO), Rome. http://www.fao.org/3/a-i2469e

[2] Kpodékon M, Tomagnimena P (1992). Acceptabilité de la viande de lapin en République du Bénin. Bulletin d'Information du Réseau de Recherche et DéveloppementCunicole en Afrique. 1: 15-21.

[3] Djago A Y, Kpodekon M, (2007). Le guide pratique de l'éleveur de lapins sous les tropiques, 2ème édition révisée. Ed. Association "Cuniculture" 31450 Corronsac, France, p.74

[4] Odunsi A A, Ogunleke M O, Alagbe O S, Ajani T O (2002). Effect of feeding Gliricidia sepium leaf meal on the performance and egg quality of layers. Int. J. Poult. Sci., 1: 26-29.

[5] Annongu A. A., M. F. Houndonougbo, J. H. Edoh \& J. I. Sanni (2016). Evaluation of toxicological and nutritional paramters of detoxified defatted dietary castor seeds in fish nutrition. Annales des Sciences Agronomiques 20 (2): 57-65.

[6] Igile G O (1996). Phytochemical and biological studies on some constituents of Vernonia amygdalia leaves. $\mathrm{PhD}$ thesis, dept. of biochemistry, University of Ibadan, Nigeria.

[7] Armstrong W D, Featherstone W R, Rogers J C (1973). The influence of methionine and other dietary addition on the performance of chicks fed birds resistant sorghum. Poult. Sci. 52:1592-1599. 
[8] Cheeke, P R and Shull L R (1985). Natural Toxicants in Feeds and Poisonous Plants. Avi. Pub. Co., Inc. Westport, C T, p.333.

[9] Fuller H L, Chang S I and Potter D K (1967). Detoxification of dietary tannic acid by chicks. J. Nutr. 91:477-481.

[10] Edoh J H, Annongu A A, Houndonougbo F M, Houndonougbo P V, Ajide S O (2019). Assay of detoxification potential of dl methionine on dietary gliricidia leaf meal in rabbit nutrition: relative organ weight and blood indices. International Journal of Advanced Research and Publications. 3(4): 47-53.

[11] Blasco A, Ouhayoun J (1996). Harmonization of criteria and Terminology in rabbit meat research. Revised proposal. World Rabbit Sci., 4: 93-99. https://doi.org/10.4995/wrs.1996.278

[12] AOAC (1990). Association of Official Analytical Chemists, Official methods of Analysis.15th edition, Washington, D. C.

[13] Pearson D (1976). Chemical Analysis of Foods. 7th Ed. Livingstone, London Church. 11:7-11.

[14] Trease G E, Evans W C (1978). A text book of pharmacognosy. 11: Bailliere-Tindall, London, p.622.

[15] Reddy M B, Love M (1999). The impact of food processing on the nutritional quality of vitamins and minerals. Adv. Exp. Med. Biol. 459: 99-106.

[16] Day R A, Underwood L A (1986). Quantitative analysis. 5th ed. New Delhi, India: Prentice hall public, p.701.

[17] Birk Y, Bondi A, Gestetner B, Ishaya IA (1968). Thermostable hemolytic factor, in soybeans. Natural 197:1089-1090.

[18] Hudson BJF, El-Difrawi EA (1979). The sapogenins of the Seeds of Four Lupin Species. J. Plant Foods 3:181-186.

[19] Harbone J-B (1973). Phytochemical Methods, London. Chapman and Hall Ltd, pp.49-188.

[20] Glover N, (1989). Gliricidia production and use. Nitrogen Fixing Tree Association, Hawaii, USA, p.44.

[21] González-Villabos D, Palomares-Naveda R, Navarro E, Soto-Castillo G, and Quintero Moreno A (2002). The use of Gliricidia sepium in the supplementary feeding of crossbred female calves. Revista Cientifica, FCV-LUZ. 12(5) : 384-3387.

[22] Alonso R, Pedraza R M, Apori S O and Ørskov E R (2003). Some chemical and biological measurements of two constracting cultivars of Gliricidia sepium (Jacq) Kunth ex Walp. Livestock Research for Rural Development 15(7): Article $\mathrm{n}^{\circ} 48$ http://www.lrrd.org/lrrd15/7/alon157.htm

[23] Aye P A and Adegun M K (2013). Chemical Composition and some functional properties of Moringa, Leucaena and Gliricidia leaf meals. Agriculture and Biology Journal of North America ISSN Print: 2151-7517, doi: 10.5251/abjna.2013.4.1.71.77, ScienceHu $\beta$, http://www.scihub.org/ABJNA.

[24] Paranamana N, Radampola K, Bulugahapitiya V P (2015). Nutritional and anti-nutritional contents of alternative plant feed ingredients for fish feed formulation. Idian Journal of Animal Sciences 85(2): 212-215.

[25] Amata, I A (2010). The effect of feeding Gliricidia Leaf Meal (GLM) on the haematological, serological and carcass characteristics of weaned rabbits in the tropics. Agric. Biol. J. N. Am., 1(5): 1057-1060.

[26] Stewart J L, Dunsillon A J, Kassi M, Lópezortíz S, Larbi A, Premeratne S, Wina E, Vargas J E (1998). Genetic variation in the nutritive value of Gliricidia sepium acceptability, intake, digestibility and liveweight gain in small ruminants. Animal Feed Sc. and Tech 75: $114-124$

[27] Davies R H (1991). Cyanogens. (In) D’Mello F P J, Duffus C M, Duffus J H.(Eds.), Toxic Substances in Crop Plants. The Royal Society of Chemistry (Great Britain), Woodhead Publishing, pp.202-225.

[28] Cheeke, P R and Raharjo, Y.C. (1987). Evaluation of Gliricidia sepium forage and leaf meal as feedstuffs for rabbits and chickens. In Withington, D., Glover, N. and Brewbaker, J L, (eds.) Gliricidia sepium (Jacq.) Walp.: management and improvement. Nitrogen Fixing Tree Association, Waimanalo, HI, USA, pp.193-198.

[29] Wina E, Adnan J, Tangendjaja B (1993). Coumarin in Gliricidia sepium: the effect of drying, its in vitro degradation and its effect on in vitro digestibility. In Subandriyo, Gatenby R M, (eds.) Advances in small ruminant research in Indonesia.Proceedings of a workshop, Research Institute for Animal Production, Ciawi Bogor, Indonesia, pp.153-163.

[30] Aboh A B, Zoffoun G A, Djenontin A J P, Babatoundé S, Mensah G A (2013). Effect of graded levels of dry pineapple peel on digestibility and growth performance of rabbit. J Appl Biosci 67: 5271-5276.

[31] Etchu K A, Ngu G T, Yongabi K A, Woogeng I N (2013). Effect of varying level of groundnut (Arachis hypogea) haulms on the growth Performance of weaners rabbits (Oryctalagus cuniculus). Inter. J. Livest. Prod. 5: 81-87.

[32] Badet F G J, M F Houndonougbo and A A M C Chrysostome, (2015). The optimal rate of soybean (Glycine max) pods in rabbit (Oryctolagus cuniculus) feed: digestibility study and growth performances. Res. Opin. Anim. Vet. Sci., 5(10): 406-410.

[33] Kpomasse C C, M F Houndonougbo and A A M C Chrysostome, (2015). Optimal level of cowpea (Vigna unguiculata) pods in feed of growing rabbit (Oryctolagus cuniculus): Digestibility study and growth performances. Res. Opin. Anim. Vet. Sci., 5(10): 411-415.

[34] Dublecz Károly (2011). Animal nutrition. Debreceni Egyetem, Nyugat-Magyarországi Egyetem, Pannon Egyetem, Digital textbook Library, p.82. https://www.tankonyvtar.hu/hu/tartalom/tamop425/0010_1A_Book_a ngol_04_takarmanyozastan/ch04s07.html

[35] Nuhu F (2010). Effect of moringa leaf meal (MOLM) on nutrient digestibility, growth, carcass and blood indices of weaner rabbits. M.Sc. thesis in Animal Nutrition, Department of Animal Science, Faculty of Agriculture and Natural Resources, Kwame Nkrumah University of Science and Technology, Kumasi.

[36] Okereke C O (2012). Utilization of Cassava, sweet potato and Cocoyam meals as dietary sources for poultry. World J Engin Pure Appl Sci 2: 63-68.

[37] Ndimantang B, Asinobi C O, Obiakor N (2006). The effect of differen processing methods on some antinutritional factors content of Ede uhie (Xanthosoma sagittifolium) and edeocha (Colocasia esculenta). Inter J Agric Rural Develop 7: 7-14.

[38] Agwunobi L N, Angwukan P O, Cora O O, Isika M A (2002). Studies of the use of Colocasia esculenta (Taro Cocoyam) in the Diets of weaned Pigs. Trop Anim Health Prod 34:241-247.

[39] Hang D T, Preston T R (2009). Taro (Colocacia esculenta) leaves as a protein source for growing pigs in Central Viet Nam. Livestock Research for Rural Development, 21(10): Article $\mathrm{n}^{\circ} 164$. URL: http://www.lrrd.org/lrrd21/10/hang21164.htm.

[40] Hang D T, Binh L V (2013). Oxalate concentration in taro leaves and petioles and effect of added calcium on nitrogen and calcium retention in pigs given diets containing 50\% ensiled taro leaves and pentioles. Livestock Research for Rural Development, 25(4): Article ${ }^{\circ} 65$. URL: http://www.lrrd.org/lrrd25/4/hang25065.htm.

[41] Gemede H F, Ratta N (2014). Antinutritional Factors in Plant Foods: Potential Health Benefits and Adverse Effects. International Journal of Nutrition and Food Sciences. 3(4):284-289.

[42] Ayers A C, Cheeke P R and Patton N M, (1993). Effect on weanling rabbits of the addition of Polyethylene glycol, phytase, methionine and choline chloride to diets containing black locust (Robinta pseudocacia) leaf meal. In Ayers A C, (1993). Evaluation of tree forage as non-traditional feedstuff for small livestock. B.Sc. thesis, Oregon State University.

[43] Annongu A A, U ter Meulen, J O Atteh and T Chinnah (1996). Biochemical and histological alterations in the liver of the Broiler after ingestion of vegetable saponins and effects of dietary supplementation with adsorbents or methyl donor. Arch. Geflugelk, 60 (6): 267-272.

[44] Hove, E. L., Herndon, J. F. (1957). Growth of rabbits on purified diets J. Nutr. 63(2):193-199. https://doi.org/10.1093/jn/63.2.193

[45] Featherston W R, RoglerJ C (1975). Influence of tannins on the utilization of sorghum grain by rats and chicks. Nutr. Rep. Intl. 11:491-497

[46] Myer R O, Combs G E, Gorbet D W (1986). Effect of methionine addition on the feeding value of diets containing bird-resistant grain sorghum for growing finishing swine. Nutr. Reports Int. 33:843-850

[47] Kpodékon M, Yousao A K I, Djobbenou I, and Djago Y, (2005) Growth and viability performance of rabbit kids fed with pellet feed. African Review of Animal Health and Production, 3 (3-4): 222-226.

[48] Houndonougbo M F, Chrysostome C A A M, Attakpa S E, Sezan A, Dehou H B (2012). Growth Performance of Rabbits Fed Palm-Press Fibres-Based Diets. ISRN Vet. Sci. Volume 2012, Article ID 915729, p.5. http://dx.doi.org/10.5402/2012/915729

[49] Dabbou S, Gasco L, Gai F, Zoccarato I, Rotolo L, Dabbou Fekih S, Brugiapaglia A, Helal A N, and Peiretti P G (2014). Dried artichoke bracts in rabbits nutrition: effects on the carcass characteristics, meat quality and fatty-acid composition. Animal (2014), 8(9):1547-1553 https://doi.org/10.1017/S1751731114001372

[50] Lounaouci-Ouyed G, Lakabi D, Berchiche M, and Lebas F (2009). "Effects of straw supply in suplement to pellet feed poor in fibres on digestion, growth and carcass yield of Algerian local rabbits population," in Proceeding of the $13^{\text {th }}$ Rabbitry Research Days, INRA-ITAVI, pp.55-58, Le Mans, France. 